\title{
ГЕОГРАФІЯ
}

UDC 551.582.2(477.8)

Vasyl Ivanovych Zatula,

$\mathrm{PhD}$ (Geography), Associate Professor,

Department of Meteorology and Climatology of Faculty of Geography,

Taras Shevchenko National University of Kyiv, 64/13 Volodymyrska St., Kyiv, 01601, Ukraine, e-mail: vaszatula@meta.ua, https://orcid.org/0000-0001-5598-0200

\section{DECOMPOSITION AND MODELLING OF THE ANNUAL CYCLE OF METEOROLOGICAL VARIABLES IN THE UKRAINIAN CARPATHIANS}

В даній роботі аналізуються структурні особливості сезонного ходу ряду метеорологічних величин в районі Украйнських Карпат. В якості таких величин розглядалися температура повітря, кількість атмосферних опадів, дефіцит насичення, відносна вологість повітря, париіальний тиск водяної пари, атмосферний тиск на рівні станиї та на рівні моря, швидкість вітру. При иьому сам річний хід інтерпретувався як суперпозиція шести гармонік з періодом від 2 місяців до 1 року.

Найважливіші результати отримано на основі аналізу матеріалів спостережень 33 метеорологічних станцій України, 22 з яких розташовано безпосередньо в Карпатах. Дослідження трунтується на відомостях про середні місячні значення семи метеорологічних величин за кліматологічний стандартний період 1961-1990 рр. Приховані періодичності в сезонних коливаннях иих величин виявлялися та оцінювалися з допомогою методу гармонічного аналізу.

Основну увагу приділено параметрам першої (річної) та другої (піврічної) гармонік, якими в середньому пояснюється близько 94 \% загальної дисперсії метеорологічних величин. При розгляді сезонних коливань температури повітря, дефіицту насичення та париіального тиску водяної пари достатньо однієї річної гармоніки. Аналіз коливань інших величин вимагає враховувати і піврічну гармоніку. Гармоніки вищих порядків (з третього по п'ятий) необхідно брати до уваги при аналізі відносної вологості повітря, кількості атмосферних опадів, атмосферного тиску на рівні станції та швидкості вітру.

Як виявилося, структура сезонного ходу метеорологічних величин на гірських станціях і в передгір'ї помітно відрізняється. Для деяких із них встановлено статистично значущі орографічні ефекти, щуо виражаються в запізнюванні або випередженні фази річної гармоніки з висотою. Близькими є фази иієї гармоніки для метеорологічних величин, пов'язаних між собою прямими залежностями, а от величини, що пов 'язані оберненими зв 'язками, зазвичай коливаються у протифазі.

Ключові слова: річний хід; гармоніки; амплітуда; фаза; моделі; Українські Карпати; орографічні ефекти.

В. И. Затула. ДЕКОМПОЗИЦИЯ И МОДЕЛИРОВАНИЕ ГОДОВОГО ХОДА МЕТЕОРОЛОГИЧЕСКИХ ВЕЛИЧИН В УКРАИНСКИХ КАРПАТАХ. В данной работе анализируются структурные особенности сезонного хода ряда метеорологических величин в районе Украинских Карпат. В качестве таких величин рассматриваются температура воздуха, количество атмосферных осадков, дефииит насыщения, относительная влажность воздуха, парииальное давление водяного пара, атмосферное давление на уровне станции и на уровне моря, скорость ветра. При этом сам годовой ход интерпретировался как суперпозици шести гармоник с периодом от 2 месячев до 1 года.

Наиболее важные результаты получены на основе анализа материалов наблюдений 33 метеорологических станций Украины, 22 из которых расположены непосредственно в Карпатах. Исследование базируется на ведомостях о средних месячных значениях семи метеорологических величин за климатологический стандартный период 1961-1990 г2. Скрытые периодичности в сезонных колебаниях этих величин выявлялись и оченивались с помощью метода гармонического анализа.

Основное внимание уделяется параметрам первой (годовой) и второй (полугодовой) гармоник, которыми в среднем объясняется около 94 \% общей дисперсии метеорологических величин. При рассмотрении сезонных колебаний температуры воздуха, дефицита насыщения и парциильного давления водяного пара достаточно одной годовой гармоники. Анализ колебаний других величин требует учета и полугодовой гармоники. Гармоники высиих порядков (с третьего по пятый) необходимо принимать во внимание при анализе относительной влажности воздуха, количества атмосферных осадков, атмосферного давления на уровне станции и скорости ветра.

Как оказалось, структура сезонного хода метеорологических величин на горных станциях и в предгорье заметно отличается. Для некоторых из них обнаружены статистически значимые орографические эффекты, которые выражаются 6 запаздывании или опережении фазы годовой гармоники с высотой. Близкими есть фазы этой гармоники для метеорологических величин, связанных между собой прямыми зависимостями, а вот величины, связанные обратными связями, обычно колеблются в противофазе.

Ключевые слова: годовой ход; гармоники; амплитуда; фаза; модели; Украинские Kарпаты; орографические эффекты.

Introduction. Effective use of climatic resources requires integrated consideration of climatic conditions fluctuations stipulated by the processes of heat, water, and atmospheric circulation. Most of them may be repeated in time with certain regularity. Oscillations are quasiperiodic in case of continuous changes of its amplitudes and periods. However, fluctuations with a clear periodic nature are more interesting. Daily and annual cycles play especially important role in nature. Data on fluctuations of both types is an integral part of an area's climatological characteristic.

Formulation of the problem. At all stages of atmospheric sciences development, considerable attention has been paid to the annual cycle of meteorological variables (MVs) which is inherent in the time 
series of these sciences. Similarly to a daily cycle, it is generated by the Earth's climatic system influenced by periodic fluctuations in solar radiation supply to the upper atmosphere. Annual fluctuations of some MVs (atmospheric pressure, in the first place) may be triggered by gravitational interaction between the Earth and the Sun, however, they are of secondary importance.

Annual cycle analysis is usually based on contrasting long-term average seasonal (or monthly) values of variables or their anomalies. Obtaining the whole complex of data has traditionally completed the annual cycle analysis, which does not always meet practical needs. That is why in search of more accurate and informative annual cycle indicators some special research methods have been commonly applied lately, with the method of harmonic analysis as one of them. It is interesting that works on its use in meteorology date back as far as the end of the $19^{\text {th }}$ century [1].

Analysis of recent research and publications. In some works, only the annual harmonic conditioned by the Earth's rotation around the Sun was considered a basic component of the annual cycle of MVs. In particular, sinusoidal approximation of the annual cycle was used to estimate long-term changes in average daily air temperature in the territory of Russia and the countries it borders on [31]. In other works, the semiannual harmonic was considered in addition to the annual harmonic, with the focus on the former one [5, $9,16,22,30]$. In general, seasonal fluctuations of MVs are more correctly described by the first harmonics which complement each other, not by one harmonic $[3,4,12,14]$.

The importance and universality of the annual cycle as a natural periodical process cannot be questioned. Thus, in extratropical latitudes of the Northern hemisphere it normally determines over $90 \%$ of the total variance of the air temperature series [10], which makes it a major climatic signal. Spatial distribution of the contribution the annual cycle makes to the total variance of this variable and some other variables for a considerable part of the World Ocean is shown in [12]. In [13] not only spatial distribution of the annual harmonic characteristics for air temperature over the whole of Europe but also their relation to North Atlantic Oscillation was shown.

A comparative characteristic of seasonal fluctuations of various MVs for a limited number of stations in Ukraine is given in [18]. Then, the annual cycle of these variables was found to be noticeably different, conditioned by the heterogeneity of the underlying surface construction which varies from region to region. Along with that, the issue of similarity or difference of the climatic conditions of these variables in the territory of some particular mountainous country remains unresolved. The author did not consider this question in subsequent papers [17, 19-20], devoted to the identification of hidden periodicities of MVs seasonal oscillations in certain regions of the East European Plain.

Further on, we consider the climatic conditions of the Ukrainian Carpathians - a separate link of a huge (about 1,500 km long) arc of the Carpathian Mountains located in Ukraine. Mountain ridges, divided by longitudinal depressions and demarcated by deep transverse valleys, stretch for $280 \mathrm{~km}$ from northwest to southeast, and 100-110 km from northeast to southwest. The area of the mountain system is about 24,000 sq km, and together with the Ciscarpathian Upland and Transcarpathian Lowland - 37,000 sq $\mathrm{km}$. The Ukrainian Carpathians are mainly the mountains of medium elevation, with the highest points of 1,000-1,200 $\mathrm{m}$. The height of six peaks in a mountain range of Chornohora exceeds 2,000 m, with Mount Hoverla $(2,061 \mathrm{~m})$ being the highest peak of Ukraine. However, since they do not reach the snow line, there are no evident traces of young glaciation. The nature of the region is very similar to that of Western Europe's. The climate in the Ukrainian Carpathians is humid and comparatively warm with the pronounced vertical zonation [29].

Despite their territorial compactness, the Ukrainian Carpathians as a separate taxonomic unit of physical and geographical zoning of the Carpathian mountainous country are determined by a considerable variety of radiation and circulation conditions stipulating climate formation. On the whole, the climate of the Carpathians can be considered well-studied, which is proven by many monographs dedicated to it $[15,24,27]$. At the same time, amplitude-phase characteristics of even basic MVs of this area have hardly ever been explored.

Purpose of the article. The main aim of this work is to establish a consistent pattern of the annual cycle of several MVs on the territory of Ukrainian Carpathians by means of harmonic analysis. Special attention was paid to spatial arrangement of annual cycle peculiarities.

Data and methods. This research is based on the average monthly values (climatological normals) of seven MVs in the Ukrainian Carpathians within a standard climatological period of 1961-1990. This observation-based data have been provided by 22 weather stations located in the considered region (Fig. 1, red marks). Moreover, the data of another 11 neighboring stations were used in the construction of maps (Fig. 1, white marks). The basic results have been obtained with the harmonic analysis method applied to the average monthly values of such MVs as air temperature, some characteristics of air humidity, monthly sums of precipitations, wind speed, and station level pressure. The last variable has been opted for due to the completeness of data (data on sea level 


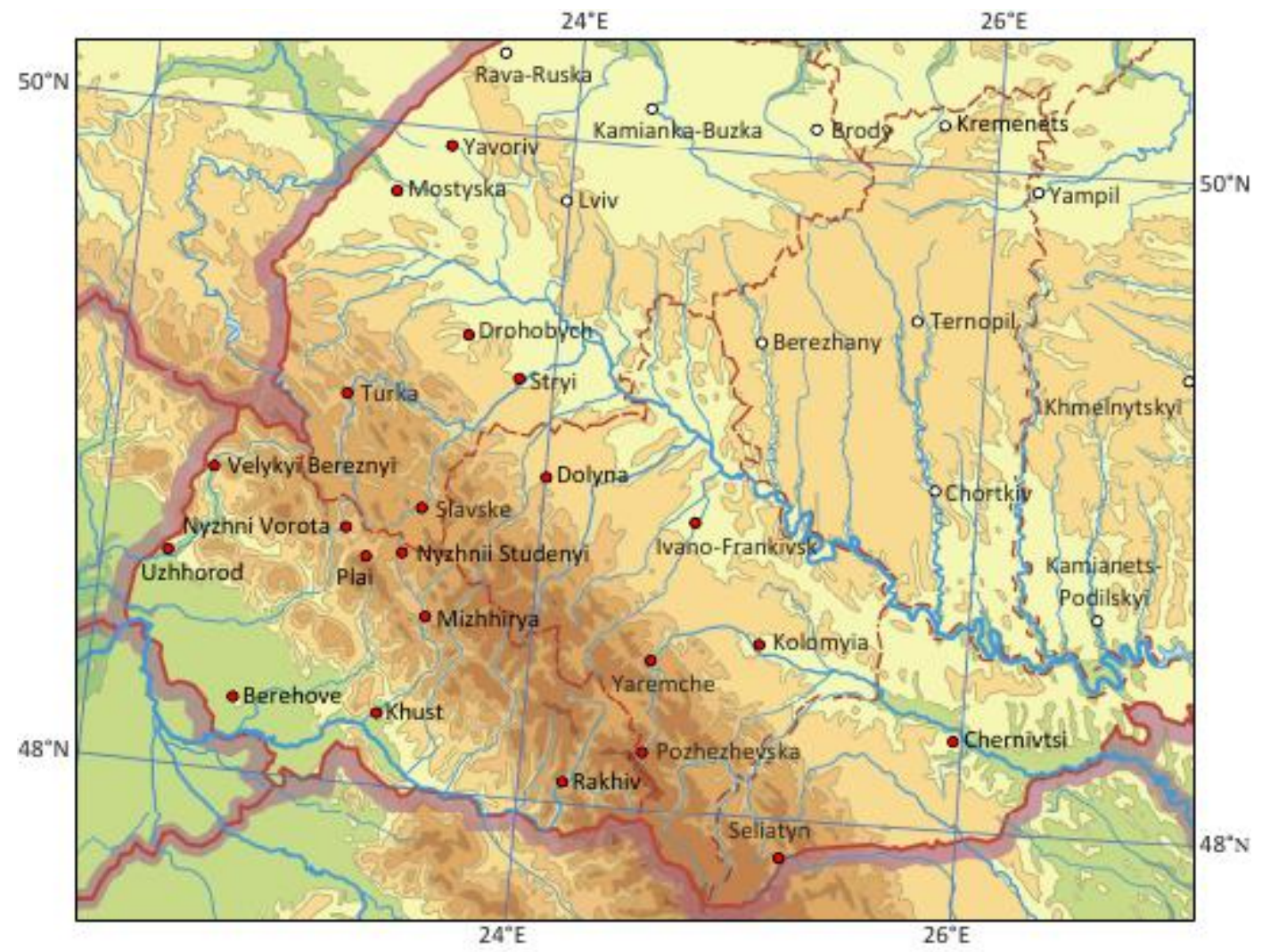

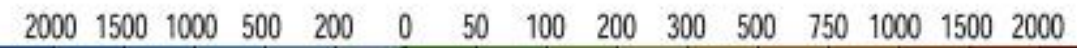

Fig. 1. A network of weather stations in the Ukrainian Carpathians and the adjacent areas of the East European Plain

pressure for stations with the highest hypsometric position is not published in reference literature on climatology).

Mathematically, the annual cycle can be interpreted as a complex (polyharmonic) fluctuation of an MV during a year, with its general features described by the first (fundamental) harmonic that will be completed by fluctuations caused by the second and higher order harmonics. The last harmonics can be viewed as the overtones of the annual cycle since their frequencies are a multiple of the fundamental frequency.

Implicit frequency in seasonal fluctuations of MV monthly values were revealed and estimated with the use of harmonic analysis method, whose classical scheme implies that any value can be presented as an arithmetical mean and a finite amount of harmonics $[7,11,23]$ :

$x_{t}=\bar{x}+\sum_{i=1}^{n / 2}\left[A_{i} \sin \left(\frac{2 \pi}{n} i t\right)+B_{i} \cos \left(\frac{2 \pi}{n} i t\right)\right]$

where $x_{t}$ is mean value for month $t(t=1,2, \ldots, 12)$; $\bar{x}$ - mean annual value of MV; $i$ - the ordinal number of a harmonic; $n=12$ - the original series length.
The unknown coefficients $A_{i}$ and $B_{i}$ were calculated by the formulas:

$$
\begin{aligned}
& A_{i}=\frac{2}{n} \sum_{t=1}^{n}\left[x_{t} \sin \left(\frac{2 \pi}{n} i t\right)\right], \\
& B_{i}=\frac{2}{n} \sum_{t=1}^{n}\left[x_{t} \cos \left(\frac{2 \pi}{n} i t\right)\right] .
\end{aligned}
$$

For the last $(i=n / 2)$ harmonic $A_{i}=0$, while $B_{i}$ was halved.

The amplitude of a harmonic is its important characteristic

$$
C_{i}=\sqrt{A_{i}^{2}+B_{i}^{2}}
$$

Periodic fluctuations of MV, conditioned by a particular harmonic, were presented as the product

$$
C_{i} \cos \left[\frac{2 \pi}{n}\left(t-t_{i}\right)\right] \text {, }
$$

where

$$
t_{i}=\frac{n}{2 \pi i} \operatorname{arctg}\left(A_{i} / B_{i}\right)-
$$

the phase, that is time when the $i$-th harmonic reaches its maximum (month). The necessary guidelines for choosing the correct phase value outside the main 
domain of the $t_{i}$ for different values of the Fourier coefficients can be found in [23].

The theory of harmonic analysis shows that the variance due to a single harmonic is $C_{i}^{2} / 2$, except for the last harmonic for which its value is twice as big. Thus, the contribution a single harmonic makes to the total variance of MV can be found by the formula

$$
f_{i}=\frac{C_{i}^{2}}{2 \sigma^{2}} \cdot 100,
$$

where $\sigma^{2}$ is the total variance. For the last harmonic value $f_{i}$ is doubled.

Spatial localization of some features of climatic conditions was evaluated with the use of regression analysis.

Presentation of the main research material. The use of standard climate indicators has methodologically limited this work to covering a small subrange of climatic conditions fluctuations, with the period varying from 2 to 12 months. Fluctuations with the period longer than 12 months as well as fluctuations of a synoptic scale were not covered by the study. At the same time, this made it possible to obtain amplitude-phase characteristics of the annual harmonic along with five more reference harmonics with multiple frequencies.

In a study with the use of harmonic analysis, a special attention is paid to the amplitude of the most significant harmonics. However, amplitude characteristics of particular harmonics for different MVs will vary not only in the order of their values but also in their dimensions. Thus, when cross analyzing and comparing the revealed frequencies of these values indicator $f_{i}$ should be used (Table 1).

According to Table 1, the first, or fundamental, harmonics play the leading role in seasonal fluctuations of all variables (the average value $f_{1}>50 \%$ ).

A physical nature of these fluctuations has already been considered. It is evident and doesn't need any additional explaining. Generally, in 79 cases out of 142 it is the annual harmonics that determine more than $90 \%$ of the total variance. Their contribution to fluctuations of air temperature $(99.4 \%)$, saturation deficit $(98.8 \%)$, and water vapour pressure $(98.6 \%)$ can hardly be overestimated.

Table 1

Main parameters average estimation of particular harmonics in some MVs in the Ukrainian Carpathians

\begin{tabular}{|c|c|c|c|c|c|c|}
\hline \multirow{4}{*}{ Meteorological variable } & \multicolumn{6}{|c|}{ Harmonic } \\
\hline & 1-st & 2-nd & 3-rd & 4-th & 5-th & 6-th \\
\hline & \multicolumn{6}{|c|}{ Period of oscillations, months } \\
\hline & 12 & 6 & 4 & 3 & 2.4 & 2 \\
\hline \multicolumn{7}{|c|}{ amplitude of harmonic: } \\
\hline Air temperature, ${ }^{\circ} \mathrm{C}$ & 10.62 & 0.70 & 0.24 & 0.23 & 0.11 & 0.05 \\
\hline Sum of precipitations, $\mathrm{mm}$ & 31.34 & 17.59 & 4.03 & 4.31 & 2.57 & 0.80 \\
\hline Saturation deficit, $\mathrm{hPa}$ & 2.48 & 0.13 & 0.15 & 0.12 & 0.05 & 0.02 \\
\hline Relative humidity, \% & 4.81 & 1.50 & 0.59 & 0.93 & 0.29 & 0.13 \\
\hline Water vapour pressure, $\mathrm{hPa}$ & 5.30 & 0.59 & 0.06 & 0.19 & 0.04 & 0.02 \\
\hline Station level pressure, $\mathrm{hPa}$ & 2.59 & 0.47 & 0.85 & 0.20 & 0.59 & 0.18 \\
\hline Wind speed, $\mathrm{m} / \mathrm{s}$ & 0.52 & 0.12 & 0.10 & 0.05 & 0.06 & 0.03 \\
\hline \multicolumn{7}{|c|}{ contribution a single harmonic makes to the total variance of MV, \%: } \\
\hline Air temperature & 99.43 & 0.44 & 0.06 & 0.05 & 0.02 & 0.00 \\
\hline Sum of precipitations & 67.61 & 27.50 & 1.77 & 2.19 & 0.77 & 0.15 \\
\hline Saturation deficit & 98.79 & 0.31 & 0.39 & 0.33 & 0.15 & 0.03 \\
\hline Relative humidity & 81.26 & 8.95 & 2.92 & 5.33 & 1.21 & 0.33 \\
\hline Water vapour pressure & 98.60 & 1.24 & 0.02 & 0.13 & 0.01 & 0.00 \\
\hline Station level pressure & 79.45 & 3.55 & 10.51 & 0.62 & 4.92 & 0.94 \\
\hline Wind speed & 82.24 & 8.63 & 5.24 & 1.19 & 2.05 & 0.65 \\
\hline mean & 86.77 & 7.23 & 2.99 & 1.41 & 1.31 & 0.30 \\
\hline \multicolumn{7}{|c|}{ phase of harmonic, months: } \\
\hline Air temperature & 7.07 & 4.16 & 2.45 & 2.06 & 1.90 & 0.00 \\
\hline Sum of precipitations & 6.82 & 0.29 & 2.92 & 2.07 & 1.36 & 0.00 \\
\hline Saturation deficit & 6.72 & 1.66 & 0.78 & 1.36 & 0.55 & 0.00 \\
\hline Relative humidity & 10.36 & 0.85 & 2.34 & 2.60 & 1.52 & 0.00 \\
\hline Water vapour pressure & 7.22 & 1.19 & 2.14 & 2.26 & 0.77 & 0.00 \\
\hline Station level pressure & 10.07 & 2.88 & 1.70 & 0.97 & 0.44 & 0.00 \\
\hline Wind speed & 2.20 & 4.49 & 3.10 & 0.98 & 1.55 & 0.00 \\
\hline
\end{tabular}


The total contribution of higher harmonics at all weather stations located in the Ukrainian Carpathians is below $1 \%$ for air temperature, with only $1-2 \%$ for water vapour pressure and $0.4-4.5 \%$ for saturation deficit. In these cases, higher harmonics can be considered insignificant (with $f_{i} \geq 5 \%$ taken as a criterion of significance). Thus, all of them can be disregarded.

The annual harmonic contributes considerably to seasonal fluctuations of wind speed (53-96\%) and station level pressure (69-93\%). It is only at one alpine weather station (Pozhezhevska, 1,451m above the sea level) that this harmonic does not contribute significantly to relative humidity seasonal fluctuations (9.6\%), following the four higher order harmonics. In case of sum of precipitations, the number of such exceptions has grown to five, with three low weather stations (Khust $-7.7 \%$, Uzhhorod $-38.4 \%$, Berehove $-48.1 \%$ ) having joined two mountain stations (Plai, $1,330 m-42.7 \%$, Rakhiv, $430 m-41.2 \%$ ). It is interesting that here the role of the annual harmonic weakened on the background of a considerable strengthening of the semiannual harmonic (Plai - 54.2\%, Rakhiv $-51.5 \%$, Khust $-75.2 \%$, Uzhhorod $-56.7 \%$, Berehove $-46.0 \%)$. Geographically, the fact that these weather stations are located within the Transcarpathian Lowland and on the slopes exposed to the winds unites them.

As we know, the semiannual harmonic is most appropriate to describe the annual cycle of MVs with two maximum and two minimum values. A similar cycle is typical of the seasonal distribution of the above-mentioned MVs - sum of precipitations ( $\left.f_{2}=27.5 \%\right)$, relative humidity $(8.9 \%)$, and wind speed $(8.6 \%)$, with indicator $f_{2}$ showing considerable spatial volatility for sum of precipitations (from 9.9\% in Yaremche to $75.2 \%$ in Khust), moderate volatility for wind speed (from $0.4 \%$ in Chernivtsi to $37.3 \%$ in Uzhhorod) and a more even distribution for relative humidity (from $2.1 \%$ in Drohobych to $19.3 \%$ at Pozhezhevska station). In some cases, station level pressure can show noticeable values of indicator $f_{2}$. At four out of ten weather stations it can reach the mark of 5-6\%. It can be assumed that such differences in this indicator distribution are influenced by factors of varying scale. Fluctuations of a planetary scale are triggered by the mode of solar radiation supply as well as meridional circulation between summer and winter hemispheres of the Earth [22]. The fluctuations of MVs modulated by them should also be considerable, which is conditioned by thermobaric interactions in the system atmosphere - ocean - dry land in the Atlantic European sector. Finally, being influenced by local peculiarities of underlying surface (orographic factor) fluctuations with less spatial distinction can be generated.
The third harmonic (with a period of 4 months) in a series of geophysical variables may be caused by changes in atmospheric circulation in intra-tropic latitudes resulting from the yearly motion of the Sun [28]. This signal spreads to other parts of a climatic system via numerous mechanisms of direct and inverse links.

A global nature of 4-month cycles is to be determined, in the first place, in atmospheric pressure fluctuations, which can be seen from data provided, since a relevant harmonic makes a significant contribution to station level pressure annual cycle (10.5\%). However, a more in-depth analysis reveals the importance of the absolute altitude. It was found that the third harmonic can be disregarded when evaluating atmospheric pressure fluctuations at alpine weather stations (Plai and Pozhezhevska), though at other stations this variable causes rather noticeable disturbance in the annual cycle of this variable. In Kolomyia, the contribution the third harmonic makes reaches $16.2 \%$ of the total variance. Moreover, the third harmonic determines considerable fluctuations of some other MVs: wind speed (this variable makes major contribution at six weather stations), sum of precipitations and relative humidity (three stations each).

Harmonics of still higher orders are usually very weak. The reasoning behind physical cause of these fluctuations lies far beyond this work and can arouse more discussion. The grounded analysis of some of them can be found in [21].

The fourth harmonic (with a period of 3 months) can be noticed only in seasonal fluctuations of relative humidity ( 8 weather stations) and sum of precipitations ( 2 stations). The fifth harmonic (with a period of 2.4 months) gains importance in the fluctuations of atmospheric pressure (6 weather stations), relative humidity (only for mountain weather stations: Pozhezhevska $-11.2 \%$, Plai $-6.8 \%$ ), and wind speed (Slavske-5.2\%). The sixth harmonic (with a period of 2 months) can be disregarded in all cases.

Data given in Table 1 support the idea that with the higher order of harmonic the variance caused by this harmonic diminishes [18]. A considerable contribution (5\% and more) to the total variance of the annual cycle of MVs of several higher order harmonics becomes possible with dramatic decrease in value of the annual harmonic.

Distribution of $f_{i}$ values is similar at individual weather stations in the Ukrainian Carpathians. The ratio of arithmetical mean and standard deviation by station sampling proves it right for more than one first harmonics to be considered in statistical models of the annual cycle of MVs.

Data on the distribution of such indicator as amplitude ratio between semiannual and annual harmonics for different MVs is given in Table 2.

Table 2 shows that in case of MVs for which an- 
Ratio of amplitudes between semiannual and annual harmonics of some MVs, percentage

\begin{tabular}{|c|c|c|c|c|c|c|c|}
\hline \multirow[b]{2}{*}{ Weather station } & \multicolumn{7}{|c|}{ Meteorological variable } \\
\hline & 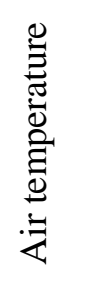 & 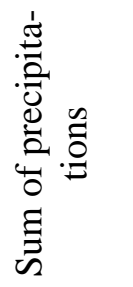 & 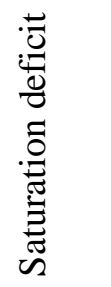 & 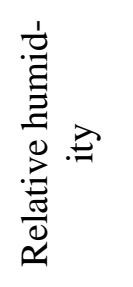 & 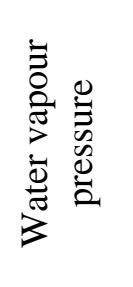 & 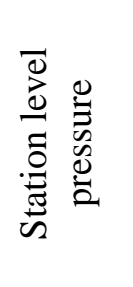 & 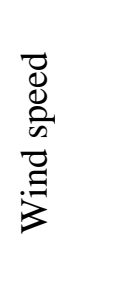 \\
\hline Yavoriv & 5.6 & 59.3 & 5.8 & 27.3 & 11.4 & - & 10.1 \\
\hline Mostyska & 6.6 & 43.6 & 8.2 & 29.2 & 10.9 & - & 17.5 \\
\hline Drohobych & 6.2 & 36.9 & 8.2 & 15.5 & 10.3 & 26.8 & 17.5 \\
\hline Stryi & 7.1 & 40.3 & 4.3 & 40.6 & 11.2 & - & 16.4 \\
\hline Turka & 6.9 & 49.2 & 5.8 & 47.4 & 11.3 & - & 31.2 \\
\hline Slavske & 6.3 & 44.4 & 6.6 & 19.7 & 11.3 & 21.1 & 36.7 \\
\hline Dolyna & 6.3 & 35.9 & 2.0 & 43.6 & 11.2 & - & 11.0 \\
\hline Ivano-Frankivsk & 6.9 & 41.1 & 7.2 & 23.7 & 11.3 & 28.9 & 19.3 \\
\hline Kolomyia & 7.6 & 35.8 & 5.3 & 26.5 & 10.7 & 30.5 & 26.2 \\
\hline Yaremche & 6.2 & 33.3 & 6.5 & 51.4 & 11.3 & - & 40.7 \\
\hline Pozhezhevska & 2.7 & 60.9 & 6.0 & 141.7 & 13.8 & 14.5 & 15.7 \\
\hline Velykyi Bereznyi & 7.5 & 84.8 & 4.4 & 29.7 & 11.1 & - & 38.0 \\
\hline Nyzhni Vorota & 6.7 & 57.3 & 2.7 & 31.2 & 10.4 & - & 28.3 \\
\hline Nyzhnii Studenyi & 6.6 & 61.5 & 6.3 & 22.7 & 10.5 & - & 27.0 \\
\hline Uzhhorod & 8.3 & 121.5 & 4.9 & 34.3 & 10.8 & 9.8 & 83.7 \\
\hline Plai & 2.0 & 112.7 & 4.8 & 35.9 & 12.3 & 9.2 & 36.6 \\
\hline Mizhhirya & 7.3 & 76.7 & 4.7 & 27.2 & 10.6 & - & 28.7 \\
\hline Berehove & 8.1 & 97.8 & 7.1 & 28.3 & 9.3 & - & 57.7 \\
\hline Khust & 8.5 & 311.9 & 5.8 & 30.0 & 10.0 & 9.4 & 56.7 \\
\hline Rakhiv & 7.0 & 111.8 & 3.3 & 38.2 & 12.2 & - & 34.8 \\
\hline Chernivtsi & 7.1 & 46.2 & 5.0 & 26.7 & 11.7 & 28.5 & 6.6 \\
\hline Seliatyn & 6.1 & 39.0 & 2.7 & 27.3 & 12.1 & 23.7 & 23.5 \\
\hline mean & 6.5 & 72.8 & 5.3 & 36.3 & 11.2 & 20.2 & 30.2 \\
\hline maximum & 8.5 & 311.9 & 8.2 & 141.7 & 13.8 & 30.5 & 83.7 \\
\hline minimum & 2.0 & 33.3 & 2.0 & 15.5 & 9.3 & 9.2 & 6.6 \\
\hline standard deviation & 1.5 & 60.1 & 1.7 & 25.1 & 0.9 & 8.7 & 18.1 \\
\hline
\end{tabular}

nual harmonic is of prior importance, this ratio is low, characterized by slight variations according to the data provided by stations. Thus, for saturation deficit and air temperature the amplitude of the semiannual harmonic does not exceed $8-9 \%$ in relation to the annual harmonic amplitude, while for water vapour pressure it constitutes $14 \%$. At the same time, for relative humidity and especially for sum of precipitations the amplitude of the semiannual harmonic can sometimes exceed the amplitude of the fundamental harmonic.

Since in most cases it is the first harmonic that determines most of the total variance of MVs, the maximum and the minimum values of its cycle during a year can be found by the phase value of this harmonic. In this sense, the graphs of water vapour pressure (Fig. 2) and relative humidity annual cycles (Fig. 3) are most demonstrative.
Thus, at Plai weather station the maximum value of water vapour pressure can be observed in late July ( $t_{1}=7.26$ month), while the maximum value of relative humidity - in the first half of December (11.68 month). For other weather stations in the Ukrainian Carpathians, the maximum value of water vapour pressure almost coincides in time with that at Plai station $(7.17 \div 7.26$ month). Time discrepancy in reaching the maximum value of relative humidity is far more considerable $(9.71 \div 12.19$ month).

In addition to the actual seasonal cycle of humidity elements, relevant graphs also show their model estimates obtained with the first harmonic, the first two harmonics and the first three harmonics taken into account. It is the first harmonic amplitude that best agrees with the annual cycle amplitude of a corresponding variable. With higher order harmonics taken into account, model estimates become more ac- 


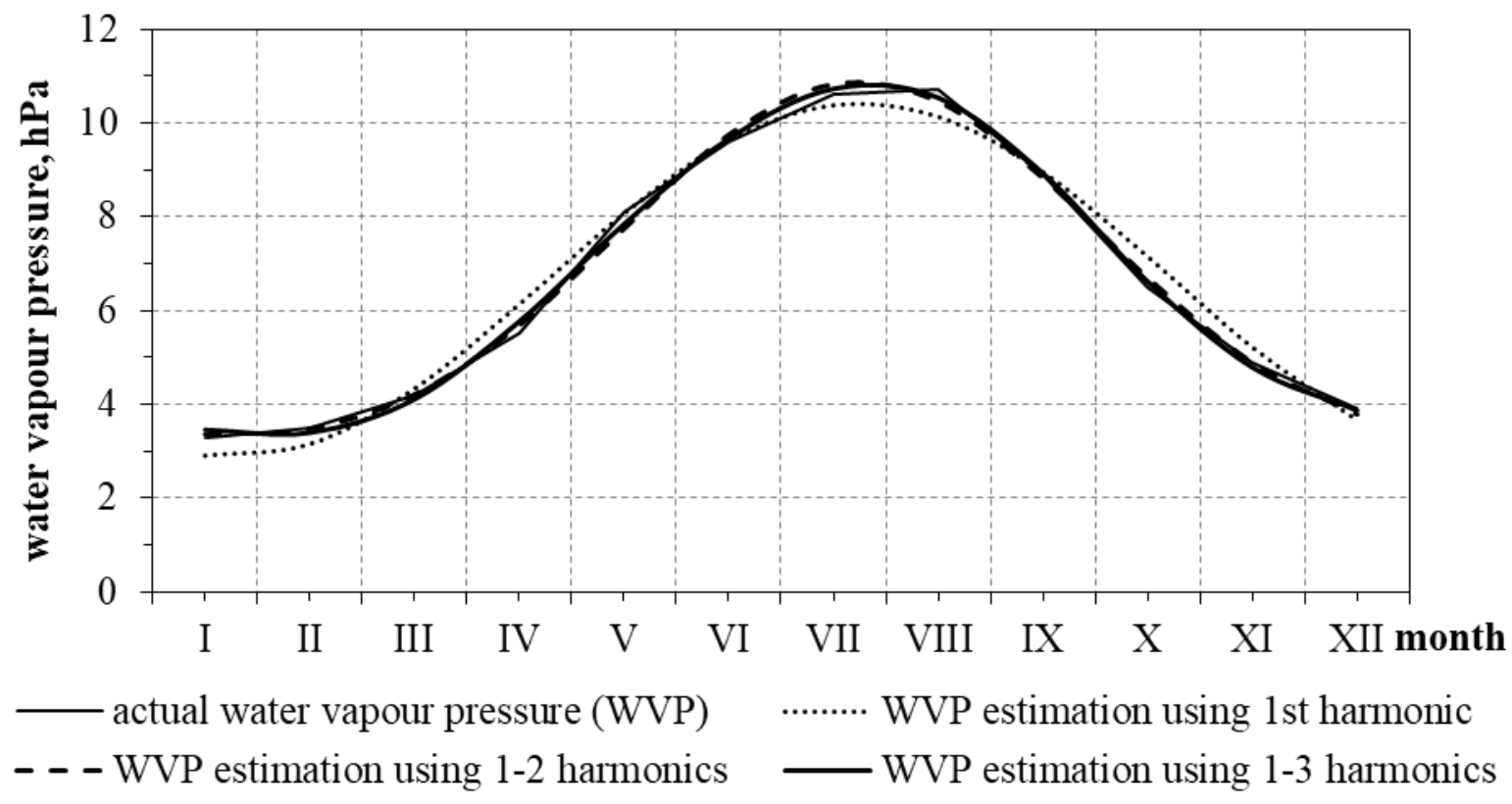

Fig. 2. Water vapour pressure annual cycle at Plai weather station

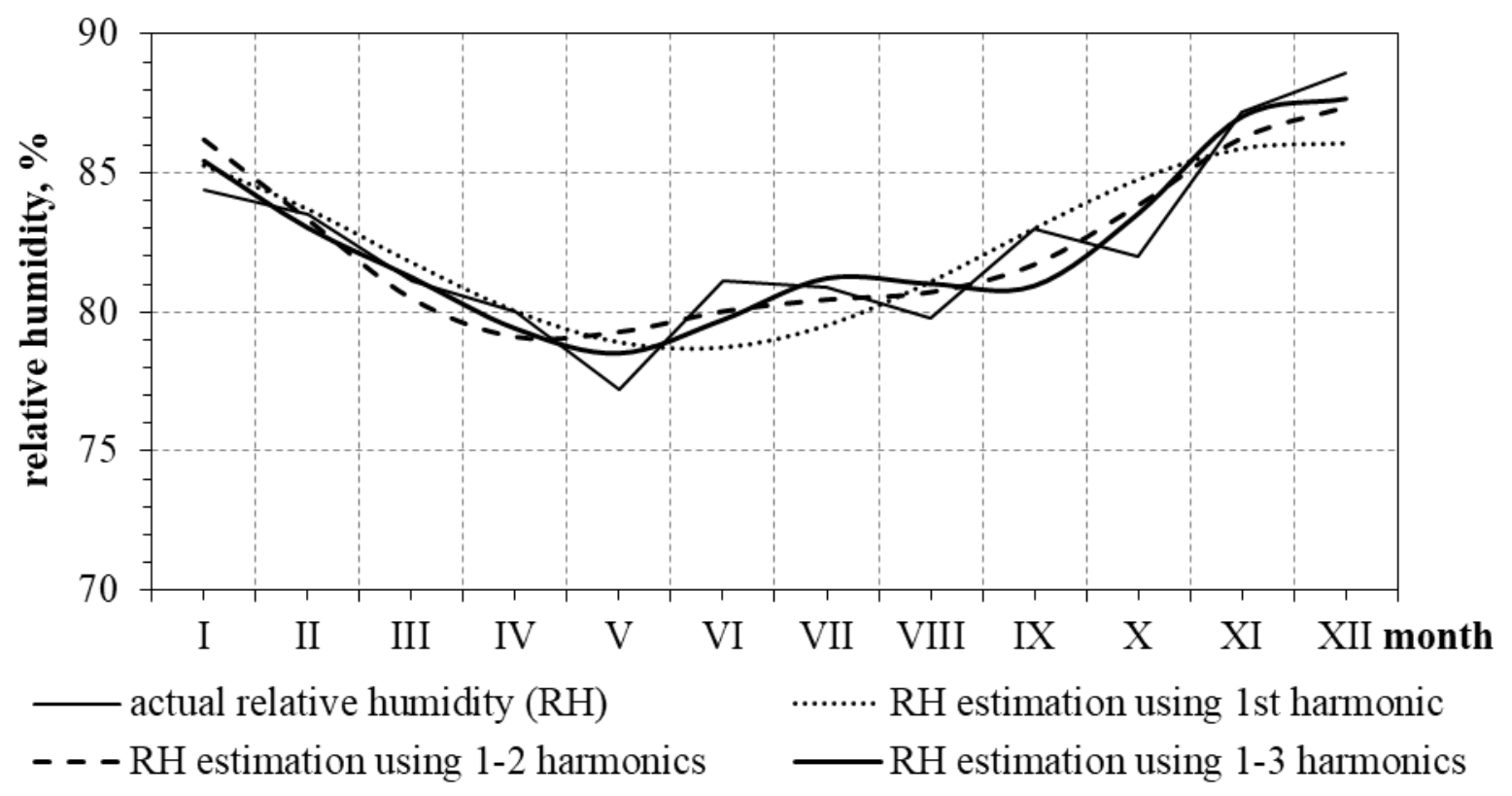

Fig. 3. Relative humidity annual cycle at Plai weather station

curate. This is more evident for relative humidity, since it is only with these variables taken into account that the model can display the minimum value in early May as well as some other peculiarities. Figure 3 shows that for a more accurate representation of peculiarities of the relative humidity annual cycle, the number of approximating harmonics should be increased (the fourth and the fifth harmonics at Plai weather station describe 5.9 and $6.8 \%$ of the total variance respectively). At the same time, in case of water vapour pressure, though, consideration of the first two harmonics - annual and semiannual - will suffice.

Normally, the maximum of the first order harmonic for meteorological variables that are directly interdependent occurs at the same time, while for those that are inversely interdependent there is a six month gap. Thus, at Plai weather station we can observe air temperature change ( $t_{1}=7.15$ month) in an almost synchronized manner along with water vapour pressure (7.26 month), saturation deficit (6.84 month) and sum of precipitations (7.23 month) associated with it. With a slight delay, the temperature itself follows seasonal changes in solar radiation (or, in the first approach, midday altitude of the Sun, with the phase angle being 6.23 months) as a determining factor of climate formation.

It is almost in antiphase that air temperature ( $t_{1}=7.15$ month), relative humidity (11.68 month), station level pressure (8.15 month), and wind speed 
(0.69 month) change. However, the cycle of atmospheric pressure (8.15 months) as well as sum of precipitations ( 7.23 months respectively) does not reveal the expected dependence. The disagreement in fluctuations of these variables can be explained by some peculiarities of a seasonal restructuring of thermobaric field in the whole of Atlantic European sector of the Northern hemisphere. It should be noted that data on the sea level pressure for Plai station is not available, while at other weather stations with a lower hypsometric position the phase of this MV was observed to be late related to station level pressure with the delay difference typically being not longer than 1 month.

It is general knowledge that the phase delay of the air temperature annual harmonic with relation to solar radiation indicates a weakened effect of large land masses $[6,8]$, and that the mountain climate has a lot in common with maritime climate [2, 26]. Given this fact, let us try to estimate the effect of Ukrainian Carpathians on the phase structure of seasonal fluctuations of individual MVs.

It was found that with an increase in altitude, the maximum of the first harmonic for a number of interrelated variables occurs with some delay (Fig. 4). Phase delay (angle of slope for trend lines in Fig. 4) is bigger for saturation deficit $(0.030 \mathrm{month} / 100 \mathrm{~m})$, moderate for air temperature $(0.014$ month $/ 100 \mathrm{~m})$ and weaker for water vapour pressure $(0.004$ month/100m). The above-mentioned delay values turned out to be statistically significant being at the 5\% significance level. Determination coefficients $R^{2}$ of linear equations $(0.560,0.639$ and 0.234 respectively) indicate medium (water vapour pressure) and high (the other two variables) degree of dependence.

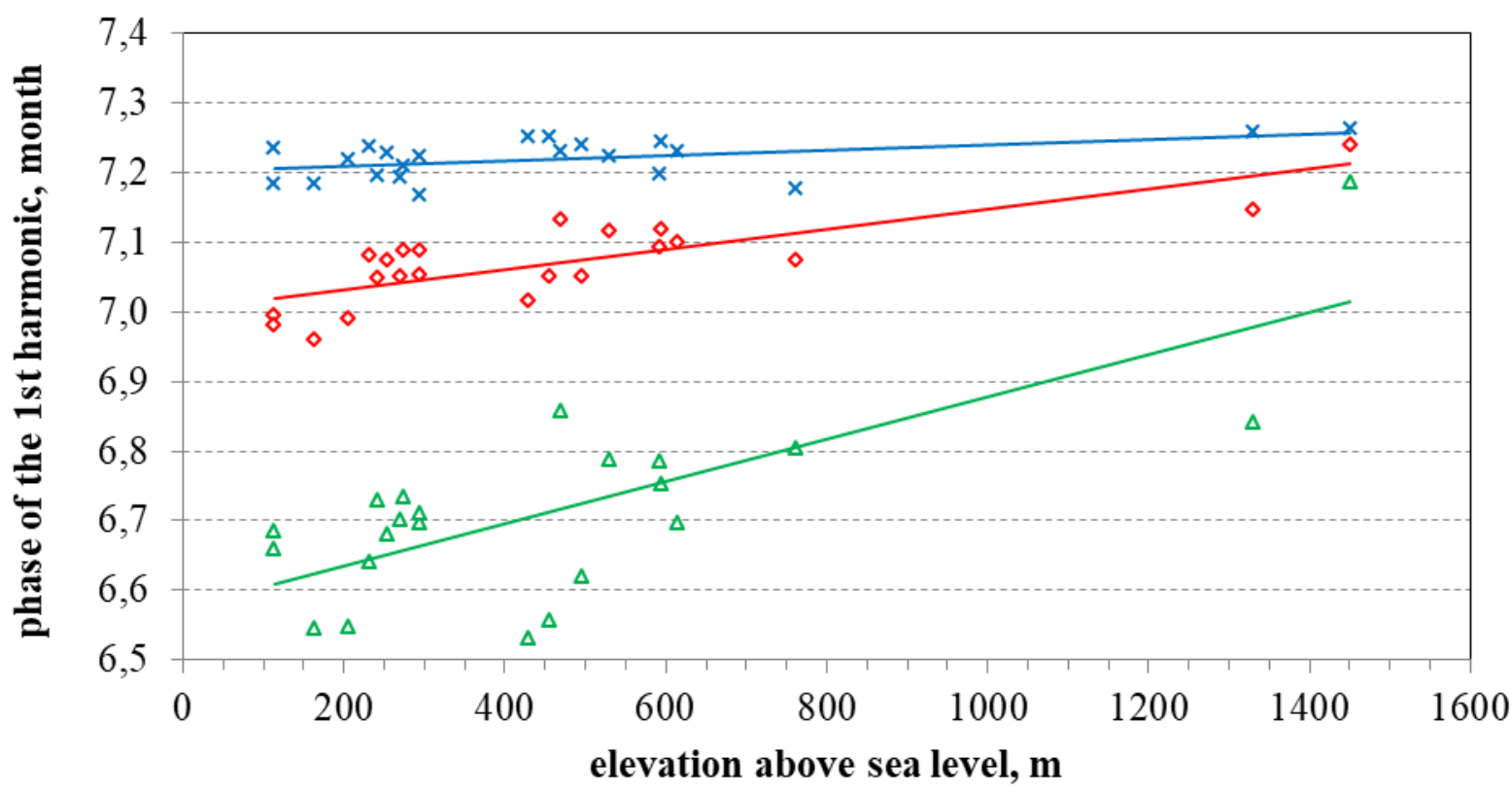

$\diamond$ air temperature $\Delta$ saturation deficit $\times$ water vapour pressure - trendline

Fig. 4. Phase delay of the first harmonic with change in altitude

The opposite tendency, namely advancing of coming of time the first harmonic maximum $t_{1}$ for station level pressure with change in altitude $(h)$, as dependency being almost linear (determination coefficient of equation $t_{1}=-0.0026 h+11.511$ is equal to 0.96 ), is also worth considering.

Time distribution for the maximum of the first harmonic to be reached in the Carpathian highlands differs significantly from that for the Transcarpathian Lowland and the adjacent areas of the East European Plain (Fig. 5).

The feature that is common for MVs, shown in the picture, is the total length of contour lines of the same phase values of this harmonic, going from northwest to southeast as well as a considerable concentration of contour lines in mountains, but the margins of this variable differing a lot. For sum of precipitations, maximum delay in the first harmonic phase is observed from the leeward side of the southwest slopes of the Ukrainian Carpathians as well as on the approach to the highest ridges of this mountain system (Fig. 5, (b)). Moving deep into the territory of Ukraine, the value of this harmonic phase goes down again. For other MVs, the area of maximum delay in the first harmonic phase is strictly localized over the highest areas of the Ukrainian Carpathians.

Thus, it is not only general climatic conditions that get milder in the Ukrainian Carpathians [15, 24, $25,27]$, but also some specific orographically deter- 

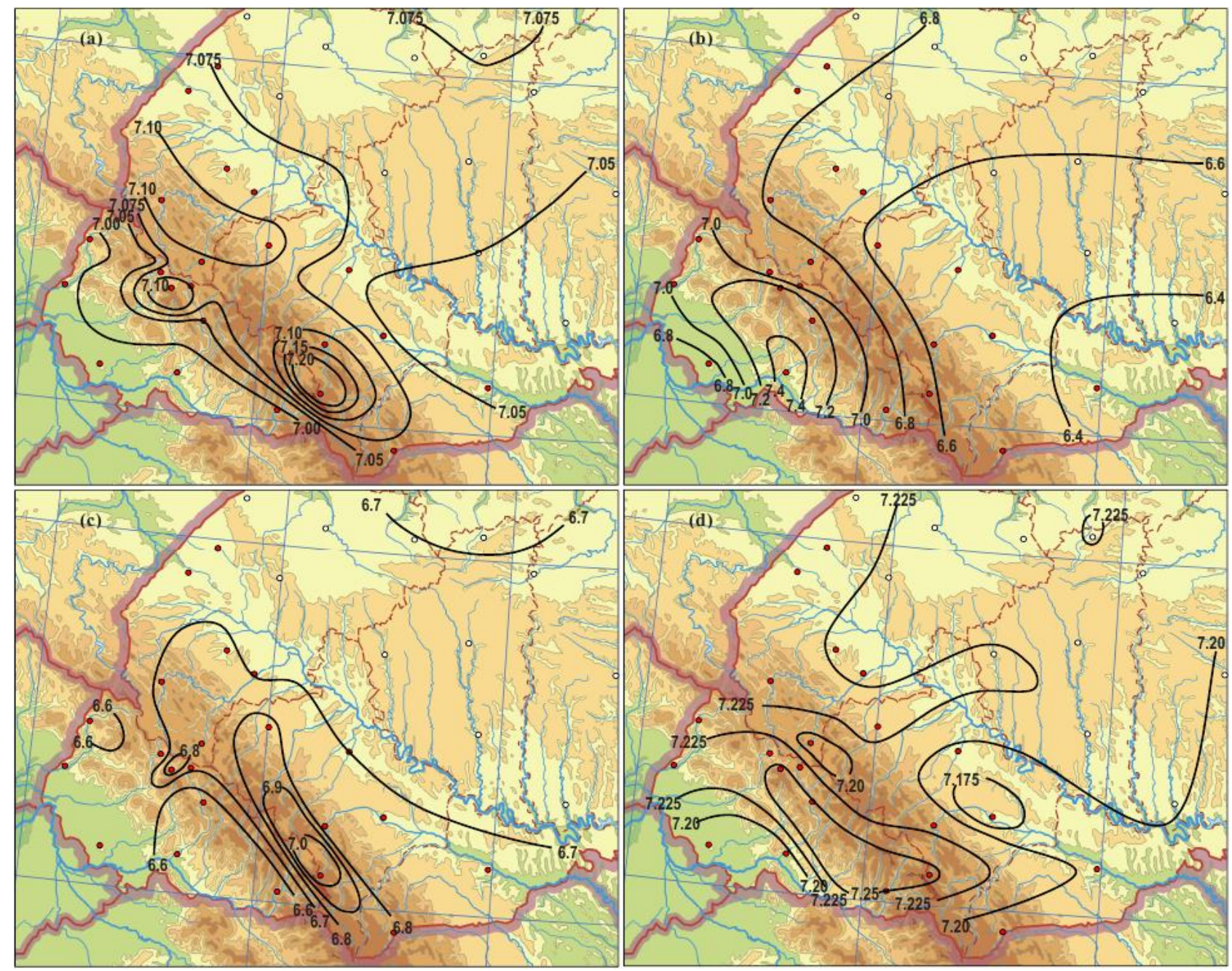

Fig. 5. Phase of first harmonic for some MVs:

(a) air temperature; (b) sum of precipitations; (c) saturation deficit; (d) water vapour pressure

mined (by the whole complex of relief conditions, or mainly due to varying altitude) effects are created, which are difficult to detect with the use of traditional methods of climatological treatment of meteorological data.

Conclusions. From the provided materials, we can see that in order to characterize polyharmonic structure of different MVs annual cycle, the value of a relative contribution that harmonic makes to the total variance of seasonal fluctuations (indicator $f_{i}$ ) proved to be most convenient. It was found that in the Ukrainian Carpathians a major contribution to fluctuations of different MVs is made by the annual and semiannual harmonics. Their aggregate contribution to the total variance of the whole complex of the climate regime parameters exceeds $94 \%$.

Most seasonal fluctuations are determined by the fundamental harmonic. In case of air temperature, saturation deficit and water vapour pressure, its contribution exceeds $98 \%$. For some more variables, its contribution makes as much as $80 \%$ and more. It was also found that the contribution the annual harmonic makes to the total variance of the seasonal cycle of some water circulation indicators (relative humidity and especially sum of precipitations) weakens in the territory of the Transcarpathian Lowland and the windward southwest macroslope of the Ukrainian Carpathians.

Semiannual harmonic gains prior importance only for sum of precipitations seasonal cycle (27.5\%). It also makes a noticeable contribution to the annual cycle of relative humidity, wind speed, and to a somewhat lesser extent to station level pressure, with indicators $f_{i}$ for these MVs showing different degrees of differentiation in space.

The third harmonic is of prior significance in atmospheric pressure fluctuations. However, its importance varies for weather stations of different hypsometrical position likely reflects the overall weakening of the effect the underlying surface produces on the atmosphere with change in altitude.

In the fluctuations of some MVs higher order harmonics have also been found, though only in some cases they determine over 5\% of the total variance. It was shown that the last harmonic (with a period of 2 months) does not play any significant role at all. 
The Ukrainian Carpathians possess some specific features of a mountain climate, with one of them being a regular change of maximum occurring for a number of MVs with change in altitude. The revealed climatic effects of delayed or early annual harmonic phase with relation to change in altitude are to be supported by research into the climate of other mountainous countries.

These materials indicate that it is essential for a number of harmonics to be taken into consideration when representing climatological features of MVs with a weakened annual cycle.

\section{References}

1. Abercromby $R$. On the application of harmonic analysis to the reduction of meteorological observations, and on the general methods of meteorology [Text] / R. Abercromby // Quarterly Journal of the Royal Meteorological Society. 1878. - Vol. 4, Issue 27. - P. 141-157. doi:10.1002/qj.4970042701

2. Barry R.G. Mountain weather and climate. 3rd edn. [Text] / R.G. Barry. - New York: Cambridge University Press, 2008. - $506 p$.

3. Craddock J.M. The representation of the annual temperature variation over central and northern Europe by a two-term harmonic form [Text] /J.M. Craddock // Quarterly Journal of the Royal Meteorological Society. - 1956. - Vol. 82, Issue 353. - P. 275-288. doi:10.1002/qj.49708235304

4. Kalma J.D. The annual course of air temperature and near-surface soil temperature in a tropical Savannah environment [Text] / J.D. Kalma // Agricultural Meteorology. - 1971. - Vol. 8. - P. 293-303. doi:10.1016/0002-1571(71)90117-8

5. Marshall G.J. On the annual and semi-annual cycles of precipitation across Antarctica [Text] / G.J. Marshall // International Journal of Climatology. - 2009. - Vol. 29, Issue 15. - P. 2298-2308. doi:10.1002/joc.1810

6. McKinnon K.A. The Spatial Structure of the Annual Cycle in Surface Temperature: Amplitude, Phase, and Lagrangian History [Text] / K.A. McKinnon, A.R. Stine, P. Huybers // Journal of Climate. - 2013. - Vol. 26. - P. $7852-7862$. doi:10.1175/JCLI-D-13-00021.1

7. Panofsky H.A. Some Applications of Statistics to Meteorology [Text] / H.A. Panofsky, G.W. Brier. - University Park: Pennsylvania state university, 1968. - 224 p.

8. Prescott J.A. The lag of temperature behind solar radiation [Text] / J.A. Prescott, J.A. Collins // Quarterly Journal of the Royal Meteorological Society. - 1951. - Vol. 77, Issue 331. - P. 121-126. doi:10.1002/qj.49707733112

9. Van den Broeke M. The semi-annual oscillation and Antarctic climate. Part 3: the role of near-surface wind speed and cloudiness [Text] / M. Van den Broeke // International Journal of Climatology. - 2000. - Vol. 20, Issue 2. - P. 117-130. doi:10.1002/(SICI)1097-0088(200002)20:2<117::AID-JOC481>3.0.CO;2-B

10. Wallace C.J. Recent and future modulation of the annual cycle [Text] / C.J. Wallace, T.J. Osborn // Climate Research. 2002. - Vol. 22, Issue 1. - P. 1-11. doi:10.3354/cr022001

11. Wilks D.S. Statistical methods in the atmospheric sciences. 2nd edn. [Text] / D.S. Wilks // Amsterdam: Academic Press, 2006. $-630 p$.

12. Yashayaev I.M. Climate of the seasonal cycle in the North Pacific and the North Atlantic oceans [Text] /I.M. Yashayaev, I.I. Zveryaev // International Journal of Climatology. - 2001. - Vol. 21, Issue 4. - P. 401-417. doi:10.1002/joc.585

13. Zveryaev I.I. Climatology and long-term variability of the annual cycle of air temperature over Europe [Text] / I.I. Zveryaev // Russian Meteorology and Hydrology. - 2007. - Vol. 32. - P. 426-430. doi:10.3103/S1068373907070023

14. Атмосфера. Справочник (справочные данные, модели) [Текст] / Редкол.: Ю.С. Седунов (председатель), С.И. Авдюшин, Е.П. Борисенков, О.А. Волковицкий, Н.Н. Петров, Р.Г. Рейтенбах, В.И. Смирнов, А.А. Черников. - Л.: Гидрометеоиздат, 1991. - 510 с.

15. Бучинський I.О. Клімат Украӥнських Карпат [Текст] / І.О. Бучинський, М.М. Волеваха, В.О. Коржов. - К.: Наукова думка, 1971. - 172 c.

16. Гирская Э.И. Полугодовые колебания атмосферного давления [Текст] / Э.И. Гирская // Труды ГГО. - 1976. Bun. 378. - C. 110-115.

17. Затула В.І. Виявлення прихованих періодичностей сезонних коливань метеорологічних величин на території Волинського Полісся [Текст] / В.I. Затула // Фізична географія та геоморфологія. - 2017. - T. 1(85). - C. $101-105$.

18. Затула В.І. Гармонічний аналіз сезонних коливань деяких метеорологічних величин на території України [Текст] / В.І. Затула, Н.I. Затула // Гідрологія, гідрохімія і гідроекологія. - 2014. - Т. 2(33). - С. 98-103.

19. Затула В.І. Виявлення прихованих періодичностей сезонних коливань метеорологічних величин на території Житомирського Полісся [Текст] / В.І. Затула, Н.І. Затула // Гідрологія, гідрохімія і гідроекологія. - 2017. T. 1(44). - C. 114-120.

20. Затула В.И. Сезонные колебания некоторых метеорологических величин на территории Одесской области [Текст] / В.И. Затула, Н.И. Затула // Вестник Гидрометцентра Черного и Азовского морей. Государственная гидрометеорологическая служба Украины. - 2017. - № 1(20). - C. 67-75.

21. Иванов В.В. Периодические колебания погоды и климата [Текст] / В.В. Иванов // Успехи физических наук. 2002. - T. 172, № 7. - C. 777-811. doi:10.1070/PU2002v045n07ABEH000948

22. Иванов-Холодный Г.С. Полугодовые вариации в аэрономии и геомагнетизме [Текст] / Г.С. Иванов-Холодный // Успехи физических наук. - 1974. - T. 114, Bыn. 2. - C. 379-381. doi:10.3367/UFNr.0114.197410i/0379

23. Исаев А.А. Статистика в метеорологии и климатологии [Текст] / А.А. Исаев. - М.: Изд-во МГУ, $1988 .-248$ с.

24. Климатические ресурсы Украинских Карпат и горных районов Болгарии [Текст] / Под ред. Л.И. Сакали и С.Х. Линговой. - М.: Моск. отд-ние Гидрометеоиздата, 1988. - 340 c. 
25. Клімат України [Текст] / За ред. В.М. Ліпінського, В.А. Дячука, В.М. Бабіченко. - К.: Вид-во Раєвського, 2003. $343 \mathrm{c.}$

26. Кобышева Н.В. Климатология [Текст]: учебник / Н.В. Кобышева, С.И. Костин, Э.А. Струнников. - Л.: Гидрометеоиздат, 1980. - 344 c.

27. Логвинов К.Т. Опасные гидрометеорологические явления в Карпатах [Текст] / К.Т. Логвинов, А.Н. Раевский, М.И. Айзенберг. - Л.: Гидрометеоиздат, 1973. - 199 с.

28. Луценко О.В. Временная изменчивость момента импульса атмосферы: автореф. дис. на соискание учен. степени канд. физ.-мат. наук : спец. 25.00.30 "метеорология, климатология, агроклиматология" / Луценко Олег Викторович; Гидрометеорол. науч.-исслед. иентр РФ. - Москва, 2003. - 22 с.

29. Маринич О.М. Фізична географія Украӥни [Текст]: підручник / О.М. Маринич, П.Г. Шищенко. - К.: Т-во «Знання», КОО, 2003. - 479 с. - ISBN 966-620-199-2.

30. Молодых В.А. Возможные причины полугодовых колебаний температуры воздуха [Текст] / B.A. Молодых, В.Ф. Логинов // Труды ГГО. - 1984. - Bып. 471. - С. 86-92.

31. Семенов С.М. Синусоидальная аппроксимация годового хода среднесуточной температуры воздуха на территории России в ХХ веке [Текст] / С.М. Семенов, Е.С. Гельвер // Метеорология и гидрология. - 2002. - № 11. C. 25-30.

UDC 551.582.2(477.8)

\section{Vasyl Zatula,}

$\mathrm{PhD}$ (Geography), Associate Professor,

Department of Meteorology and Climatology of Faculty of Geography,

Taras Shevchenko National University of Kyiv, 64/13 Volodymyrska St., Kyiv, 01601, Ukraine, e-mail: vaszatula@meta.ua, https://orcid.org/0000-0001-5598-0200

\section{DECOMPOSITION AND MODELLING OF THE ANNUAL CYCLE OF METEOROLOGICAL VARIABLES IN THE UKRAINIAN CARPATHIANS}

Formulation of the problem. In this paper we consider some structural peculiarities of the seasonal cycle of a number of meteorological variables (air temperature, sum of precipitations, saturation deficit, relative humidity, water vapour pressure, station level and sea level pressure, wind speed) in the Ukrainian Carpathians, with the annual cycle being interpreted as a superposition of six harmonics with the period ranging from 2 months to 1 year.

Data and methods. This research is based on the average monthly values of seven meteorological variables in the Ukrainian Carpathians within a standard climatological period of 1961-1990. Implicit frequencies in seasonal fluctuations were revealed and evaluated with the help of harmonic analysis method.

Presentation of the main research material. A particular emphasis has been laid on the parameters of the first (annual) and second (semiannual) harmonics. It was found out that, on average, the annual harmonic explains some $87 \%$ of the total variance of the variables, while the semiannual harmonic accounts for more than $7 \%$. It is shown that when considering seasonal fluctuations of air temperature, saturation deficit and water vapour pressure annual harmonic will suffice. Analyzing fluctuations of other meteorological variables requires a semiannual harmonic to be taken into account. Higher order harmonics (from third to fifth) are to be taken into consideration when analyzing relative humidity, sum of precipitations, station level pressure, and wind speed. The last harmonic (with a period of 2 months) does not play any significant role at all.

It was found out that the seasonal cycle structure of these meteorological variables at mountain weather stations and at foothill ones differ noticeably. For some meteorological variables, namely saturation deficit, air temperature, water vapour pressure and atmospheric pressure, orographic effects that manifest in either delayed or early phase of the annual cycle with relation to altitude, have proved to be statistically significant. Phases of this harmonic are typical of meteorological variables that are directly interdependent, while variables that are inversely interdependent normally fluctuate in antiphase.

Keywords: annual cycle, harmonics, amplitude, phase, models, Ukrainian Carpathians, orographic effects.

\section{References}

1. Abercromby R. (1878). On the application of harmonic analysis to the reduction of meteorological observations, and on the general methods of meteorology. Quarterly Journal of the Royal Meteorological Society, 4(27), $141-157$. doi:10.1002/qj.4970042701

2. Barry R.G. (2008). Mountain weather and climate. Cambridge, UK: Cambridge University Press, 506.

3. Buchy`ns`ky`j I.O., Volevaxa M.M., Korzhov V.O. (1971). Klimat Ukrayins`ky`x Karpat [Climate of the Ukrainian Carpathians]. Kyiv, Ukraine: Naukova Dumka, 172. 
4. Craddock J.M. (1956). The representation of the annual temperature variation over central and northern Europe by a twoterm harmonic form. Quarterly Journal of the Royal Meteorological Society, 82(353), $275-288$. doi:10.1002/qj.49708235304

5. Girskaja Je.I. (1976). Polugodovye kolebanija atmosfernogo davlenija [Semi-annual variations of atmospheric pressure]. Proceedings of Main Geophysical Observatory, 378, 110-115.

6. Isaev A.A. (1988). Statistika v meteorologii i klimatologii [Statistics in meteorology and climatology]. Moscow, USSR: Moscow State University, 248.

7. Ivanov V.V. (2002). Periodicheskie kolebanija pogody i klimata [Periodic weather and climate variations]. Advances in physical sciences, 172(7), 777-811. doi:10.1070/PU2002v045n07ABEH000948

8. Ivanov-Holodnyj G.S. (1974). Polugodovye variacii v ajeronomii i geomagnetizme [Semi-annual variations in aeronomy and geomagnetism]. Advances in physical sciences, 114(2), 379-381. doi:10.3367/UFNr.0114.197410i/0379

9. Kalma J.D. (1971). The annual course of air temperature and near-surface soil temperature in a tropical Savannah environment. Agricultural Meteorology, 8, 293-303. doi:10.1016/0002-1571(71)90117-8

10. Kobysheva N.V., Kostin S.I., Strunnikov Je.A. (1980). Klimatologija [Climatology]. Leningrad, USSR: Gidrometeoizdat, 344.

11. Lipins`ky`j V.M., Dyachuk V.A., Babichenko V.M. eds. (2003). Klimat Ukrayiny` [Climate of Ukraine]. Kyiv, Ukraine: Vy`davny`cztvo Rayevs kogo, 343.

12. Logvinov K.T., Raevskij A.N., Ajzenberg M.I. (1973). Opasnye gidrometeorologicheskie javlenija v Karpatah [Dangerous hydrometeorological phenomena in the Carpathians]. Leningrad, USSR: Gidrometeoizdat, 199.

13. Lucenko O.V. (2003). Vremennaja izmenchivost' momenta impul'sa atmosfery [Temporal variability of the angular momentum of the atmosphere]. Hydrometeorological research center of Russian Federation. Moscow, Russian Federation, 22.

14. Marshall G.J. (2009). On the annual and semi-annual cycles of precipitation across Antarctica. International Journal of Climatology, 29(15), 2298-2308. doi:10.1002/joc.1810

15. Mary`ny`ch O.M., Shy`shhenko P.G. (2003). Fizy`chna geografiya Ukrayiny`[Physical Geography of Ukraine]. Kyiv, Ukraine: Tovarystvo «Znannya», 479.

16. McKinnon K.A., Stine A.R., Huybers P. (2013). The Spatial Structure of the Annual Cycle in Surface Temperature: Amplitude, Phase, and Lagrangian History. Journal of Climate, 26, 7852-7862. doi:10.1175/JCLI-D-13-00021.1

17. Molodyh V.A., Loginov V.F. (1984). Vozmozhnye prichiny polugodovyh kolebanij temperatury vozduha [Possible causes of semi-annual variations in air temperature]. Proceedings of Main Geophysical Observatory, 471, 86-92.

18. Panofsky H.A., Brier G.W. (1968). Some Applications of Statistics to Meteorology. University Park, USA: Pennsylvania state university, 224.

19. Prescott J.A., Collins J.A. (1951). The lag of temperature behind solar radiation. Quarterly Journal of the Royal Meteorological Society, 77(331), 121-126. doi:10.1002/qj.49707733112

20. Sakali L.I., Lingova S.H. eds. (1988). Klimaticheskie resursy Ukrainskih Karpat i gornyh rajonov Bolgarii [Climate resources of the Ukrainian Carpathians and mountainous regions of Bulgaria]. Moscow, USSR: Gidrometeoizdat, Moskovskoe otdelenie, 340.

21. Sedunov Ju.S. (Chairman), Avdjushin S.I., Borisenkov E.P., Volkovickij O.A., Petrov N.N., Rejtenbah R.G., Smirnov V.I., Chernikov A.A. eds. (1991). Atmosfera. Spravochnik (spravochnye dannye, modeli) [Atmosphere Handbook (reference data, models)]. Leningrad, USSR: Gidrometeoizdat, 510.

22. Semenov S.M., Gel'ver E.S. (2002). Sinusoidal'naja approksimacija godovogo hoda srednesutochnoj temperatury vozduha na territorii Rossii $v$ XX veke [Sine approximation of the annual course of daily mean air temperature in Russia in the twentieth century]. Meteorology and hydrology, 11, 25-30.

23. Van den Broeke M. (2000). The semi-annual oscillation and Antarctic climate. Part 3: the role of near-surface wind speed and cloudiness. International Journal of Climatology, 20(2), 117-130. doi:10.1002/(SICI)10970088(200002)20:2<117::AID-JOC481>3.0.CO;2-B

24. Wallace C.J., Osborn T.J. (2002). Recent and future modulation of the annual cycle. Climate Research, 22(1), 1-11. doi:10.3354/cr022001

25. Wilks D.S. (2006). Statistical methods in the atmospheric sciences. 2nd edn. Amsterdam: Academic Press, 630.

26. Yashayaev I.M., Zveryaev I.I. (2001). Climate of the seasonal cycle in the North Pacific and the North Atlantic oceans. International Journal of Climatology, 21(4), 401-417. doi:10.1002/joc.585

27. Zatula V.I. (2017). Viyavlennya prihovanih periodichnostej sezonnih kolivan meteorologichnih velichin na teritoriyi Volinskogo Polissya [Identifying of the hidden periodicities of seasonal oscillations of meteorological variables on the territory of Volyn Polissya]. Physical geography and geomorphology, 1(85), 101-105.

28. Zatula V.I., Zatula N.I. (2014). Harmonic analysis of seasonal oscillations of some meteorological variables on Ukrainian territory. Hydrology, hydrochemistry and hydroecology, 2(33), 98-103.

29. Zatula V.I., Zatula N.I. (2017a). Sezonnye kolebaniya nekotoryh meteorologicheskih velichin na territorii Odesskoj oblasti [Seasonal oscillations of some meteorological variables on territory of Odessa region]. Bulletin of Hydrometeorological center of Black and Azov seas, 1(20), 67-75.

30. Zatula V.I., Zatula N.I. (2017b). Viyavlennya prihovanih periodichnostej sezonnih kolivan meteorologichnih velichin na teritoriyi Zhitomirskogo Polissya [Identifying of the hidden periodicities of seasonal oscillations of meteorological variables on the territory of Zhytomyr Polissya]. Hydrology, hydrochemistry and hydroecology, 1(44), 114-120.

31. Zveryaev I.I. (2007). Climatology and long-term variability of the annual cycle of air temperature over Europe. Russian Meteorology and Hydrology, 32, 426-430. doi:10.3103/S1068373907070023 